fruit and vegetables, where at the present time, by improvements in technical methods and the organisation of suitable supplies, an important industry is developing, so in the condensation of milk-whether to furnish evaporated (unsweetened) milk, sweetened condensed milk, or dried milk-development ought not to be difficult. The first requisite for such development is a knowledge of the raw material, and in Part $I$ of the bulletin an account is given of the influence of the various components of milk in condensing and drying. Part 2 deals with the colloidal properties of milk, as these are important with reference to coagulation by heat in the manufacturing processes, and in the alcohol test, by which the suit. ability of milk for condensing is judged. The influence of heat on milk, both as regards the bacterial flora and changes of a chemical nature, are discussed in Part 3, and the effect in both cases is shown to have important bearings upon factory methods and upon the final produet.

The manufacture of sweetened condensed milk is, as would be expected, described fully, the technical operations first being outlined. Sections on the bacteriology of the product, the control and testing of the raw milk, the bacterial flora of milk, all give a good résumé of the present state of knowledge. In the last section of Part 4 are described the defects in condensed milk, due on one hand to micro-organisms and on the other to chemical or physical changes.

In Part 5 evaporated milk is dealt with in a similar manner, and in Part 6 dried milk; in the latter Part the composition and properties of milk powders are discussed especially with reference to keeping qualities.

The waste of valuable food material in the whey from cheese factories-the loss has been estimated to be about $£ 1,000,000$ annually in Great Britain-has occasioned much thought, and a certain amount of research work has been undertaken, but so far no commercially successful method of utilising the whey has been put into operation. What has been achieved is recorded in Part 7, and it seems very probable that with the knowledge now available and the perfecting of the engineering details a food capable of being used in the confectionery and sweet trades will be manufactured economically.

The final part of the bulletin discusses the uses of condensed milk and dried milk in the household and. in industry.

The writer of the bulletin-Dr. L. A. Allen--is to be congratulated upon the thoroughness with which he has gathered together the material, and upon the skilled and critical manner in which he reviews it. In each section the points having a bearing upon the subject under discussion are clearly brought forward.

\title{
Altruism in Science and Industry
}

UNDER the title "Science and Industrial Sanity", in the Hibbert Journal for July 1932, Mr. H. P. Vowles and his late wife, Margaret Vowles, discuss some of the effects of the application of science to industry during the last century and half, particularly the enormous increase in productivity and the unaccompanying unemployment. They reject at the outset the pleas for a return to the pre-scientific age or for the suspension of scientific research and its application to industry for several decades, and point out that the spectacular increase in productive capacity has been accompanied by a considerable change in the ethical standards of industry. Wherever science has influenced industrial activity, the spirit of service has come into competition with the desire for private gain. The serious problems with which mankind is now confronted are mainly attributed to the existence of whole tracts of industry, notably those concerned with the monetary aspects of distribution, which are uninfluenced by science, and where alike the scientific method and the spirit of service have yet to penetrate.

In support of their contention, the authors refer to the noble tradition of science that the service of mankind should be given precedence over personal advancement, and to the part played by the engineer in the permeation of industrial activities with the ideal of public service. Engineering institutions and societies have all adopted the attitude that though engineers must normally earn a living by their work, the primary purpose of engineering activity is the service of man- kind. Political economy similarly became imbued with the idea that co-operation is a nobler ideal than self-interest, and to-day the idealism of the engineering societies is only one of the indications that as industry becomes more influenced by science the obligation upon all to subordinate self-seeking to the common good becomes more widely acknowledged.

Accordingly, with this change in mind, it is possible to view without dismay the enormous increase in the power resources affecting not only manual but also clerical labour, or the realisation that the mechanical invasion of mankind is only in its initial stages. The penetration of science to the world's monetary and distributive systems is bound to follow; and beyond this, the complete permeation of industry by science, involving the attainment of higher educational levels for all and producing a saner work-day environment, should be of considerable assistance in guiding men to sane uses of the leisure which will be available for all in the completely scientific State. Such rationalisation and reorganisation necessarily involve a very wide margin of leisure for all, but if science enables men to see industry in its right perspective and themselves in their right relation to industry and to one another, the fear that leisure will be used unwisely in the scientific State may never be justified in the event. Nor need we dismiss as utopian the suggestion that science and machinery, and the leisure they make possible, are destined to play an indispensable part in lifting men to new and higher levels of endeavour and achievement.

\section{Development of the 'Grid' in Great Britain}

$A^{N}$ address by Sir Archibald Page, chief engineer of $\mathrm{A}^{\mathrm{N}}$ the Central Electricity Board, on the 'grid' for electric supply in Great Britain was given recently to the Electrical Association for Women (the Electrical Age, July). Sir Archibald points out that there are three main stages of getting electricity to the consumers' terminals, namely, generation, transmission, and distribution. The Central Electricity Board is primarily concerned with the first and in a less degree with the second of these stages.

At the beginning of this century, engineers recog- nised that electricity can be produced much more cheaply in large quantities, and that electricity is the most convenient agency for the transmission of power, heat, and light. Companies possessing several stations found it advantageous to link them together. The outbreak of the War and the subsequent increased demand for power led to the appointment of the Electricity Commission to regulate and promote the production and distribution of electricity in accordance with modern ideas.

In 1925 the Weir Committee recommended the

$$
\text { No. 3275, VoL. 130] }
$$


establishment of a system of main transmission lines called the 'Grid Iron' for the purpose of interconnecting the principal generating stations of Great Britain, and in due course proposed the shutting down of less efficient stations. To effect this, a new organisation called the Central Electricity Board was set up to manage what may be called the 'wholesale' side of the supply industry. This Board is now hard at work accelerating the completion of the 4000 miles of transmission line and the numerous transforming and switching stations involved, and is already well ahead of its original programme.

Although on technical and financial grounds it was advisable to use overhead lines, it was necessary to use a considerable mileage of cable, mainly in the London district. The value of the orders given by the Board to British firms now exceeds 22 million pounds. This has reacted on unemployment figures and the electrical industry is one of the few flourishing industries in the country. The Board is in no sense a government department. It is part of the supply industry and is financially self-supporting.

Great Britain with its dense population, diversified industries, cheap coal, and extensive coast-line is an ideal country to electrify. What is needed is an efficient organisation to ensure that expansion of output which will bring cheap electricity to the consumer. The field is wide. Only about 65 per cent of the machinery utilised in industry is electrically driven. There are eleven million potential consumers in Great Britain and only about four and a quarter million are connected with the supply mains.

Sir Archibald Page pointed out that Great Britain was the first country to lay down a national system of electric trunk mains. It was now almost impossible to make a train or car journey of any distance without seeing some of the lattice steel towers supporting the electrical conductors which constitute the 'grid'.

\section{University and Educational Intelligence}

CAMbridge.-At Emmanuel College the studentship offered for competition to graduates of other universities intending to commence residence as research students in October has been awarded to L. Belchetz, Rhodes University College, Grahamstown, South Africa (chemistry). The studentship held by J. W. Harding (Victoria University College, Wellington, New Zealand) for mathematical physics has been renewed for a third year. Internal studentships offered for competition to members of the college have been awarded as follows: B. V. Bowden (physics) for one year, A. J. Ward (mathematies) for two years.

London.-The following degrees have been conferred: D.Sc. in biochemistry on Manayath Damodaran (Imperial College-RoyalCollege of Science) for a thesis on "The Amino-Acids of Gluterin" (Biochem. J., 1931), "The Dicarboxylic Acid Nitrogen of Proteins" (Biochem. J., 1931), and "The Isolation of Asparagine from an Enzyme Digest of Edestin" (Biochem. J., 1932). D.Sc. in chemistry on Ranchhodji Dajibhai Desai (Imperial College--Royal College of Science) for a thesis entitled "The Influence of Methylcyclopentane and Methylcyclohexane Rings on Carbon Tetrahedral Angle" (J. Chem. Soc., May 1931 and April 1932). D.Sc. in mining geology on Mr. G. C. A. Jackson (Imperial College-Royal School of Mines) for a thesis entitled "The Geology and Ore-deposits of the N'Changa Mine and District, Northern Rhodesia ", a portion of which, entitled "The Ores of the N'Changa Mine and Extensions, Northern Rhodesia", has been published in Economic Geology, vol. 27, No. 3, 1932. D.Sc. in psychology on Mr. S. J. F. Philpott
(University College) for a thesis entitled "Fluctuations in Human Output" (Brit. J. Psych., 1932).

IT is announced that the Prudential Assurance Company has offered to contribute $£ 1500$ a year for a term of seven years to the London School of Hygiene and Tropical Medicine. The suggestion that the contribution shall be directly associated for the duration of the gift with the University chair of public health has been accepted by the governors of the School.

The Science Scholarships Committee of the Royal Commission for the Exhibition of 1851 has made the following appointments to Overseas Scholarships for 1932 :-On the recommendation of McGill University : Mr. J. F. Heard (physics, Imperial College of Science and Technology, London), Mr. M. K. McPhail (biochemistry, National Institute for Medical Research, London); on the recommendation of Queen's University, Kingston : Mr. W. J. Henderson (physics, University of Cambridge), Mr. G. S. Farnham (metallurgy, University of Manchester); on the recommendation of the University of Melboume : Mr. A. B. Edwards (geology, Imperial College of Science and Technology, London); on the recommendation of the University of Sydney: Thelma M. Reynolds (organic chemistry, University of Oxford); on the recommendation of the Universities of Cape Town and the Witwatersrand: Dr. E. C. Halliday (physics, University of Cambridge and the Experimental Station of the Radio Research Board, Slough); on the recommendation of the University of New Zealand: Mr. R. M. Barrer (physical chemistry, University of Cambridge).

\section{Calendar of Geographical Exploration}

Aug. Io, I537.-De Vaca and the Gulf of Mexico

In 1528, Cabez de Vaca had accompanied Pamfilo de Navarez on an expedition which landed on the west coast of Florida near Tampa Bay. In a subsequent march they lost touch with their ships and the party broke up. In the winter of 1528-29, of a party of 80 on the 'Island of Misfortune' off the coast of Texas, only 15 survived. De Vaca was one; he crossed to the mainland and spent five years among the natives. Then, with a companion, he travelled south, crossing the Brazos and Colorado Rivers and reaching San Antonio Bay. Ultimately he reached Mexico City and returned to Europe, arriving at Lisbon on Aug. 10, 1537. His account of the riches of the region which he had visited resulted in the journeys of Coronado and de Soto.

\section{Aug. I I, I90I.--Kaiser Wilhelm II. Land}

Prof. von Drygalski left Kiel on Aug. 11 in the Gauss, reaching Kerguelen Island on Dec. 31, where a party of German scientific workers had landed a few months earlier and had set up an observatory. The Gauss wintered in the ice, and a sledging party discovered the land named Kaiser Wilhelm II. Land, with a hill $1500 \mathrm{ft}$. high, which was named the Gaussberg. The expedition not only discovered new land, but also recorded many valuable scientific observations.

\section{Aug. I2, I767.-Carteret's Discoveries in the Pacific}

Capt. Carteret in the Swallow, after discovering Pitcairn Island, reached the Santa Cruz group. Although these islands had been discovered by Mendaña a century before, their position was but imperfectly known and Carteret may be credited with their rediscovery. Later the group now known as the Carteret

No. 3275 , VoL. 130$]$ 